\title{
$1273 \mathrm{~K}$ における $\mathrm{FeO}-\mathrm{M}_{2} \mathrm{O}(\mathrm{M}=\mathrm{Na}, \mathrm{Li})$ 固溶体と ガス中酸素の平衡
}

\begin{abstract}
井口 義 章* 天弘 義一苂 平尾 次 郎***
J. Japan Inst.Metals, Vol.50, No.3(1986), pp.282-287

Equilibrium Between $\mathrm{FeO}-\mathrm{M}_{2} \mathrm{O}(\mathrm{M}=\mathrm{Na}$, Li) Solid Solution and

Oxygen in Gas Phase at $1273 \mathrm{~K}$

Yoshiaki Iguchi*, Yoshikazu Amahiro** and Jiro Hirao***

The compositions of $\mathrm{FeO}-\mathrm{M}_{2} \mathrm{O}(\mathrm{M}=\mathrm{Na}$, $\mathrm{Li})$ solid solution in equilibrium with $\mathrm{Ar}-\mathrm{H}_{2}-\mathrm{H}_{2} \mathrm{O}$ mixture of fixed compositions at $1273 \mathrm{~K}$ were determined by analysis by means of a reduction method and a fire flame method. The concentration of cation vacancy calculated on the assumption of no interstitial cation-defect was smaller than that in hypothetical ideal binary solutions $\mathrm{FeO}-\mathrm{M}_{2} \mathrm{O}$. The vacancy concentration was tried to be calculated as a function of the content of $\mathrm{M}_{2} \mathrm{O}$ in the consideration of two external reactions, (13) and (14). The values of $\log K_{13}$ and $\log K_{14}$ were able to be expressed by linear functions of the concentration of $M$ in the lattice, although the apparent equilibrium constants were dependent on the defect concentration and oxygen pressure.
\end{abstract}

(Received October 18, 1985)

Keywords : wustite solid solution, alkaline metals, cation vacancy association, redox equilibria

\section{I. 緒言}

$\mathrm{Fe}-\mathrm{Na}-\mathrm{O}$ 系の酸化物は, 高炉内反応, 原子炉の泠却剂 としての液体ナトリウム中の溶存酸素によるステンレスの 腐食反応において重要である。この系の状態図とその中の 複合酸化物の熱力学的研究は最も新しいStaffansson らの 研究(1)をはじめいくつかの研究(2)-(12) が 報告されている。 しかしこの系のウスタイト固溶体については, Fe ある いは $\mathrm{Fe}_{3} \mathrm{O}_{4}$ 固溶体と平衡にあるウスタイト固溶体について の Balkhi ら (2)(11), Staffansson らの研究(1)があるにすぎ ない.

本研究は酸素分圧一定のもとで平衡させたウスタイト固 溶体の組成を分析することによって，ウスタイト固溶体の 熱力学的研究を行った。 また， Na と同じIa 族に属する Li の酸化物を含むウスタイトについても研究した。たた し, $\mathrm{K} は \mathrm{~K}_{2} \mathrm{O}$ の蒸気圧が高く，本研究で採用した方法で は実験できなかった。

\section{II. 試料}

\section{1. 平衡試料の調製}

試薬特級の $\mathrm{Fe}_{2} \mathrm{O}_{3}$ (関東化学(株)), $\mathrm{Na}_{2} \mathrm{CO}_{3}, \mathrm{Li}_{2} \mathrm{CO}_{3}$ を出 発物質として使用した。 $\mathrm{Fe}_{2} \mathrm{O}_{3}$ は $1573 \mathrm{~K}$ での $3.6 \mathrm{ks}$ の焼
成, 粉砕の後, 250 mesh 以下の粉体として使用した。 十 分に乾燥した粉体を科量し，高純度アルミナ乳鉢で $1.8 \mathrm{ks}$ 混合し, 直径 $1.5 \mathrm{~cm}$ 約 $3 \mathrm{~g}$ のタブレットに圧縮成型した. このタブレット状圧粉体を白金ボートに入れ，1173，1273 $\mathrm{K}$ で $P_{\mathrm{H}_{2} \mathrm{O}} / P_{\mathrm{H}_{2}}$ 比を調整した $\mathrm{Ar}-\mathrm{H}_{2}-\mathrm{H}_{2} \mathrm{O}$ 混合ガスと反応 させた，反応は 3 段階で進行する。第 1 段階 $(28.8 \mathrm{ks})$ で は,まず $\mathrm{Ar}-\mathrm{H}_{2}-\mathrm{H}_{2} \mathrm{O}$ 混合ガス中で $\mathrm{Fe}_{2} \mathrm{O}_{3}$ の $\mathrm{FeO}$ への還 元, $\mathrm{M}_{2} \mathrm{CO}_{3}(\mathrm{M}: \mathrm{Na}, \mathrm{Li})$ の $\mathrm{M}_{2} \mathrm{O}$ への分解, $\mathrm{M}_{2} \mathrm{O}$ の $\mathrm{FeO}$ 中 への固溶が進行する。第 2 段階 $(129.6 \mathrm{ks})$ では精製された $\mathrm{Ar}$ 中で $\mathrm{M}_{2} \mathrm{O}$ の $\mathrm{FeO}$ 中への固溶が十分に進行する。そし て, 第 3 段階 $(21.6 \mathrm{ks})$ では, $\mathrm{Ar}-\mathrm{H}_{2}-\mathrm{H}_{2} \mathrm{O}$ 混合ガス中で $\mathrm{FeO}$ 固溶体と雾囲気ガスとの平衡が進行する。ただし， $1173 \mathrm{~K}$ での平衡試料の調製では，第 2 段階の反応を $\mathrm{Ar}$ 雲囲気中で $1273 \mathrm{~K}$ に打いて $151.2 \mathrm{ks}$ 行い, $\mathrm{M}_{2} \mathrm{O}$ の $\mathrm{FeO}$ 中への均一固溶を促進させた。 $\mathrm{M}_{2} \mathrm{O}$ の蒸気圧が前報(13)の $\mathrm{MeO}(\mathrm{Me}=\mathrm{Ca}, \mathrm{Sr}, \mathrm{Ba})$ と比較して高いので, 圧粉体から の $\mathrm{M}_{2} \mathrm{O}$ の蒸発を防ぐため, 圧粉体は同じ組成の粉体混合 物中に埋め込まれた。異種酸化物の科量時混合割合と反応 条件を Table 1 に示した，反㢁の終了した試料は，反応 温度で十分に Ar ガスに置換したのち, $1073 \mathrm{~K}$ まで炉冷 し，その後反応管を炉から取り出して冷却した。

な㧍，本研究の実験方法では，1373 K 以上の温度では

* 名古屋工業大学材料工学科 (Department of Materials Science and Engineering, Nagoya Institute of Technology, Nagoya)

** 名古屋工業大学大学院生, 現在 : 愛知製鋼株式会社 (Graduate Student, Nagoya Institute of Technology, Nagoya. Present address: Aichi Steel Works Ltd., Tokai)

*** 名古屋工業大学名誉教授 (Emeritus Professor, Nagoya Institute of Technology) 
Table 1 Mole ratio of $\mathrm{Fe}$ to $\mathrm{Na}$ or $\mathrm{Li}$ in the mixtures of starting materials and experimental condition for the equilibration between wustite solid solution and oxygen in the gas phase.

\begin{tabular}{c|c|c|c}
\hline \multicolumn{2}{c|}{ Mole ratio } & Temperature $(\mathrm{K})$ & $P_{\mathrm{H}_{2} \mathrm{O}} / P_{\mathrm{H}_{2}}$ \\
\cline { 2 - 4 }$n_{\mathrm{Fe}}: n_{\mathrm{Na}}$ & $97.5: 2.5$ & 1173 & $35 / 65$ \\
& $95.0: 5.0$ & & $50 / 50$ \\
& $92.9: 7.1$ & 1273 & $30 / 70$ \\
& & & $15 / 85$ \\
\hline & & 1173 & $35 / 65$ \\
\hline$n_{\mathrm{Fe}}: n_{\mathrm{Li}}$ & $97.5: 2.5$ & & $50 / 50$ \\
& $95.0: 5.0$ & & $30 / 70$ \\
& $92.5: 7.5$ & 1273 & $15 / 85$ \\
\hline
\end{tabular}

平衡試料調製時の $\mathrm{M}_{2} \mathrm{O}$ の蒸発により，1073 K 以下の温度 では平衡到達時間の指数関数的増加のための困難を伴うた め実験は $1273 \mathrm{~K}$ で行い, 一部の実験を $1173 \mathrm{~K}$ で行った。

\section{2. $\mathrm{M}_{2} \mathrm{O}$ の $\mathrm{FeO}$ 中への固溶の確認}

まず，X線ディフラクトメーターを使用して $\mathrm{CoK}_{\boldsymbol{\alpha}}$ 線に よるX線回折を行い, $\mathrm{FeO}$ 固溶体の格子定数を測定した。 $\cos ^{2} \theta \rightarrow 0$ への外插によって得られた格子定数と $n_{\mathrm{M}} /\left(n_{\mathrm{Fe}}\right.$ $\left.+n_{\mathrm{M}}\right)$ 比の関係を Fig.1 に示す。ここで $n_{\mathrm{M}}, n_{\mathrm{Fe}}$ は $\mathrm{FeO}$ 固溶体中の $\mathrm{M}, \mathrm{Fe}$ の $\mathrm{mol}$ 数である. $\mathrm{Na}_{2} \mathrm{O}$ を固溶した $\mathrm{FeO}, \mathrm{Li}_{2} \mathrm{O}$ を固溶した $\mathrm{FeO}$ ともに直線関係を示し添加し た $\mathrm{M}_{2} \mathrm{CO}_{3}$ から生成した $\mathrm{M}_{2} \mathrm{O}$ の全量が $\mathrm{FeO}$ 中に固溶した と推定される。一部の試料についての試料調製時間をさら に $72 \mathrm{ks}$ 延長した平衡試料の格子定数も Fig.1 の直線関係 の標準偏差内にあった。

さらに, 平衡試料を切断研磨後 EPMA による分析を行 ったが析出物は見られず一定の強度分布を示した。

以上のことから，平衡試料調製の反応時間は本研究の条 件で十分であり, 共存する $\mathrm{M}_{2} \mathrm{O}$ の全量が $\mathrm{FeO}$ 中に固溶し たと推定される。

$E$

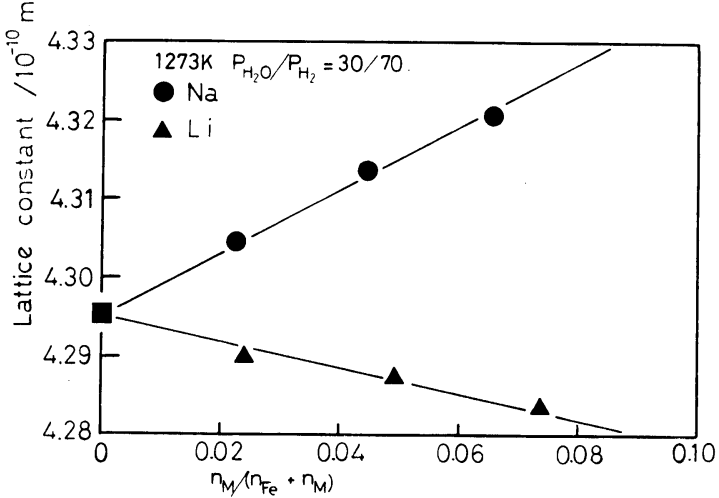

Fig.1 Change in the lattice parameter of wustite solid solution with the doping of $\mathrm{Na}_{2} \mathrm{O}$ and $\mathrm{Li}_{2} \mathrm{O}$.

\section{III. 平衡試料の分析}

\section{1. 分 析 法}

ウスタイトを冷却するときに起こりらる $\mathrm{Fe}_{3} \mathrm{O}_{4}$ の析出 と, $833 \mathrm{~K}$ に打壮る共析分解は，水中に急冷しても防ぎ切
れないことが分かっている(14)ので，その影響を直接受け る 2 価と 3 価の鉄を化学分析するよりも分解・析出の影響 を受けない水素還元法を採用した，水素還元法では，前 報 ${ }^{(13)}$ に打ける異種酸化物 $\mathrm{MeO}$ と異なり，本研究に扣ける $\mathrm{Na}_{2} \mathrm{O}$ は還元され易く, $\mathrm{Na}$ とて蒸発するため, 平衡試料 とその還元試料中の Mの濃度も炎光分析により決定した.

作製した平衡試料 4 個のらち 3 個を純 $\mathrm{Ni}$ 板製ボート $(15 \mathrm{~mm} \times 15 \mathrm{~mm} \times 3 \mathrm{~mm}$ 約 $0.8 \mathrm{~g})$ に 1 個ずつ入れ, 1373 $\mathrm{K}$ で $14.4 \mathrm{ks}$ 水素で還元した，還元後も白金アスベスト炉 と乾燥剤を通して精製した $\mathrm{H}_{2}$ 中で室温まで泠却して，取 り出したのちただちに科量した。この際 $\mathrm{Ni}$ ボートの質量 変化は全く観察されなかった。

炎光分析により，平衡試料 4 個のらち 1 個と還元された 平衡試料 3 個のらち 1 個についてMの濃度を決定した．分 析に際しては, 各試料を SS 級塩酸 $20 \mathrm{~cm}^{3}$ に溶解し, 蒸 留水で $1000 \mathrm{~cm}^{3}$ に希釈した。標準溶液は $\mathrm{Fe}$ と $\mathrm{C} 1$ につい て分析試料と同じ濃度になるように調製した。

\section{2. 分析値からの成分分率の計算}

平衡試料中の元素 $\mathrm{Fe}, \mathrm{Na}, \mathrm{O}$ の $\mathrm{mol}$ 数, $n_{\mathrm{Fe}}, n_{\mathrm{Na}}, n_{\mathrm{O}}$ を決定するためには各元素の質量 $W_{\mathrm{Fe}}, W_{\mathrm{Na}}, W_{\mathrm{O}}$ を決定 しなければならない，熱力学データによって検討すると $\mathrm{Na}_{2} \mathrm{O}$ は還元され易いので還元された平衡試料は $\mathrm{Fe}$ と $\mathrm{Na}$ から構成されているとして，つぎの計算を行った。

$$
\begin{aligned}
& W_{\mathrm{Fe}}=W_{\mathrm{Fe}, \mathrm{Na}^{*}}-W_{\mathrm{Na}^{*}} \\
& W_{\mathrm{Na}}=C_{\mathrm{Na}} \cdot W_{(\mathrm{Fe}, \mathrm{Na}) \mathrm{O}} \\
& W_{\mathrm{O}}=W_{(\mathrm{Fe}, \mathrm{Na}) \mathrm{O}}-W_{\mathrm{Fe}}-W_{\mathrm{Na}}
\end{aligned}
$$

ここで， $\quad W_{\mathrm{Fe}, \mathrm{Na}^{*}}$ : 還元後の平衡試料の質量 $(\mathrm{mg})$ $W_{\mathrm{Na}^{*}}$ : 還元後の平衡試料中の $\mathrm{Na}$ の質量

$C_{\mathrm{Na}}$ : 平衡試料中の $\mathrm{Na}$ の濃度 $(\mathrm{mg} \mathrm{Na} \cdot(\mathrm{mg}$

$W_{(\mathrm{Fe}, \mathrm{Na}) \mathrm{O}}$ : 平衡試料の質量 $(\mathrm{mg})$ 試料) ${ }^{-1}$ ) さらに $W_{\mathrm{Na}^{*}}$ はつぎの関係から求めた.

$$
W_{\mathrm{Na}^{*}}=C_{\mathrm{Na}^{*}} \cdot W_{\mathrm{Fe}, \mathrm{Na}^{*}}
$$

ここで $C_{\mathrm{Na}^{*}}$ : 還元された平衡試料中の $\mathrm{Na}$ 濃度 $(\mathrm{mgNa}$ $\left(\mathrm{mg}\right.$ 試料) ${ }^{-1}$ )

一方 $\mathrm{Li}_{2} \mathrm{O}$ を含む平衡試料については, 熱力学データか ら $\mathrm{Li}_{2} \mathrm{O}$ は珤とんど還元されないと考えられるので還元さ れた平衡試料は $\mathrm{Fe}$ と $\mathrm{Li}_{2} \mathrm{O}$ から構成されているとして計

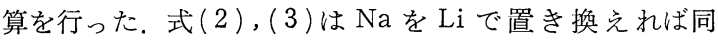
じ式が利用できる。式(1)，(4)の代りに式 (5)，(6)を使 った。

$$
\begin{gathered}
W_{\mathrm{Fe}}=W_{\mathrm{Fe}, \mathrm{Li}_{2} \mathrm{O}}^{*}-W_{\mathrm{Li}_{2} \mathrm{O}}^{*} \\
W_{\mathrm{Li}_{2} \mathrm{O}}=\frac{M_{\mathrm{Li}_{2} \mathrm{O}}}{2 M_{\mathrm{Li}}} \cdot C_{\mathrm{Li}}^{*} \cdot W_{\mathrm{Fe}, \mathrm{Li}_{2} \mathrm{O}}^{*}
\end{gathered}
$$

ここで $W_{\mathrm{Fe}, \mathrm{Li}_{2} \mathrm{O}}{ }^{*}$ : 還元後の平衡試料の質量 $(\mathrm{mg})$

$W_{\mathrm{Li}_{2} \mathrm{O}}{ }^{*}$ : 還元後の平衡試料中の $\mathrm{Li}_{2} \mathrm{O}$ の質量

$C_{\mathrm{L}}$ : : 還元された平衡試料中の $\mathrm{Li} の$ 濃度 $\left(\mathrm{mg} \mathrm{Li} \cdot\left(\mathrm{mg}\right.\right.$ 試料 $\left.\left.^{-1}\right)\right)$

$M_{\mathrm{Li}}, M_{\mathrm{Li}_{2} \mathrm{O}}$ : Li の原子量, $\mathrm{Li}_{2} \mathrm{O}$ の分子量 
以上の計算式によって $n_{\mathrm{Fe}}, n_{\mathrm{M}}, n_{\mathrm{O}}$ が求められる.さら に，カチオンの侵入型欠陥はないとの仮定のもとに，カチ オンサイトの総数に対するカチオン構成要素 $\mathrm{Fe} \mathrm{Fe}_{\mathrm{r}}, \mathrm{Fe} \mathrm{Fe}_{\mathrm{e}}$, $\mathrm{M}_{\mathrm{Fe}}^{\prime}, \mathrm{V}_{\mathrm{Fe}}^{\prime \prime}$ の占めるサイトの分率は式 $(7) \sim(10)$ によって 求めることができる.

$$
\begin{aligned}
& \left(\mathrm{M}_{\mathrm{Fe}}^{\prime}\right)=n_{\mathrm{M}} / n_{\mathrm{O}} \\
& \left(\mathrm{V}_{\mathrm{Fe}}^{\prime \prime}\right)=1-\left(n_{\mathrm{Fe}}+n_{\mathrm{M}}\right) / n_{\mathrm{O}} \\
& \left(\mathrm{Fe}_{\mathrm{Fe}}\right)=2\left(\mathrm{~V}_{\mathrm{Fe}}^{\prime}\right)+\left(\mathrm{M}_{\mathrm{Fe}}^{\prime}\right) \\
& \left(\mathrm{Fe}_{\mathrm{Fe}}^{\times}\right)=1-\left(\mathrm{M}_{\mathrm{Fe}}^{\prime}\right)-\left(\mathrm{V}_{\mathrm{Fe}}^{\prime \prime}\right)-\left(\mathrm{Fe}_{\mathrm{Fe}}\right)
\end{aligned}
$$

カチオン構成要素の表示は Kröger とVink の表示法(15) によった。また各構成要素の分率は（）で囲んで $\left(\mathrm{M}_{\mathrm{Fe}}^{\prime}\right)$ 等 で表わした。

\section{IV. 実 験 結 果}

III.2の計算式によって平衡試料中の構成元素の質量と $\mathrm{mol}$ 数を求めた。 その結果をウスタイト領域中の等酸素圧 線として, Balkhi ら (2)(11) とよって報告されている Fig.2 の $\mathrm{FeO}-\mathrm{Fe}_{2} \mathrm{O}_{3}-\mathrm{Na}_{2} \mathrm{O} 3$ 元系の $1273 \mathrm{~K}$ に打ける等温断面図 上にプロットした.さらに $Y=n_{\mathrm{M}} /\left(n_{\mathrm{Fe}}+n_{\mathrm{M}}\right)$ と $X=n_{\mathrm{O}} /$ $\left(n_{\mathrm{Fe}}+n_{\mathrm{M}}\right)$ の関係として Fig.3, 4 にプロットした。また Fig.3, 4 には $\mathrm{Fe}_{x_{0}} \mathrm{O}$ を $\mathrm{M}_{2} \mathrm{O}$ で単純に希釈したときの $Y$ と $X$ の関係を

$$
\begin{aligned}
& Y=2 N_{\mathrm{M}_{2} \mathrm{O}} /\left(N_{\mathrm{FeO}} \cdot x_{0}+2 N_{\mathrm{M}_{2} \mathrm{O}}\right) \\
& X=1 /\left(N_{\mathrm{FeO}} \cdot x_{0}+2 N_{\mathrm{M}_{2} \mathrm{O}}\right)
\end{aligned}
$$

から計算して一点鎖線で示した。ここで, $N_{\mathrm{FeO}}, N_{\mathrm{M}_{2} \mathrm{O}}$ は $\mathrm{Fe}_{x_{0}} \mathrm{O}$ と $\mathrm{M}_{2} \mathrm{O}$ 総 mol 数に対する $\mathrm{Fe}_{x_{0}} \mathrm{O}, \mathrm{M}_{2} \mathrm{O}$ の $\mathrm{mol}$ 分 率を示すパラメーターである。

いずれの実験結果も一点鎖線の関係より $X$ 值が小さい ことが注目される。

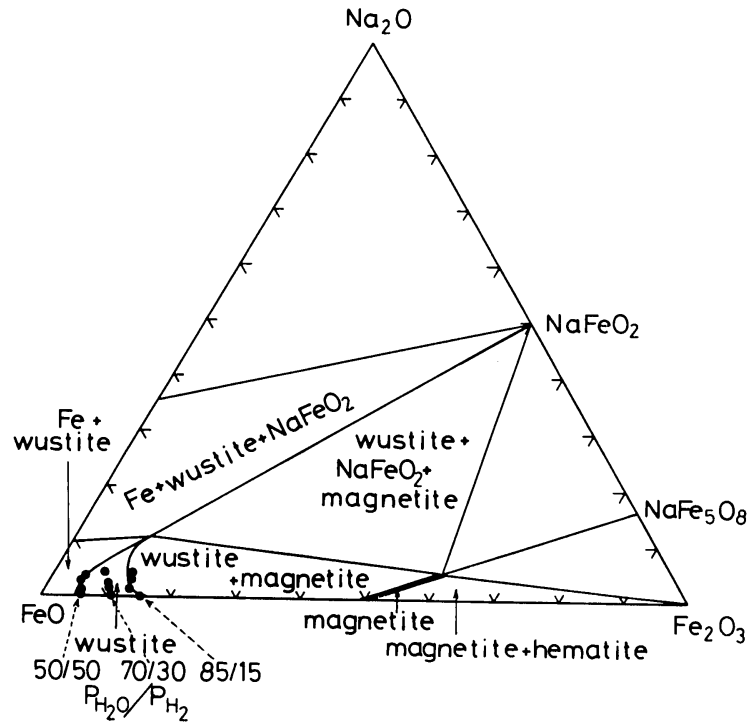

Fig.2 Variation in the composition of wustite with the dissolution of $\mathrm{Na}_{2} \mathrm{O}$ at three pressures of oxygen at $1273 \mathrm{~K}$, which was superposed the $\mathrm{FeO}-\mathrm{Fe}_{2} \mathrm{O}_{3}$ $\mathrm{Na}_{2} \mathrm{O}$ phase diagram at $1273 \mathrm{~K}$ by Balkhi et al(2).

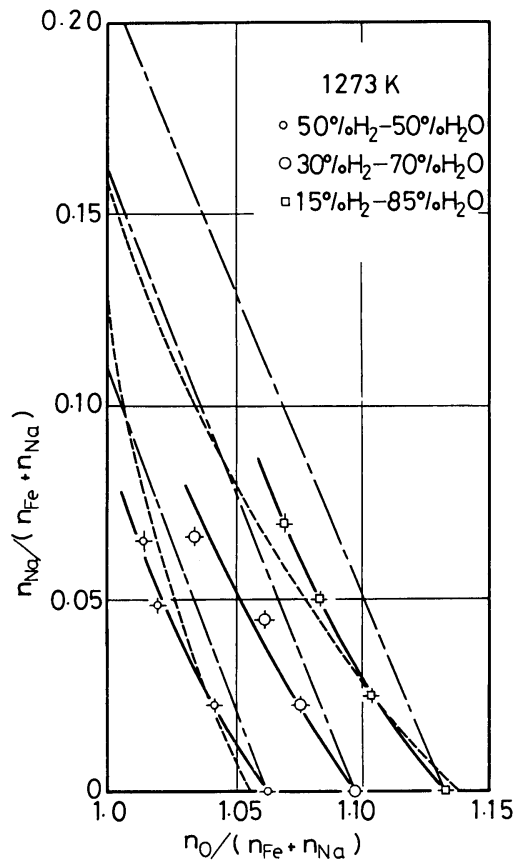

Fig. 3 Variation of $Y$ (mole fraction of $\mathrm{Na}$ to total moles of metals) with $X$ (mole fraction of oxygen to total moles of metals) at the three pressures of oxygen. -..-- : phase boundaries of wustite solid solution. : relation between $Y$ and $X$ calculated on the assumption of an ideal solid solution in the binary system of $\mathrm{FeO}-\mathrm{Na}_{2} \mathrm{O}$.

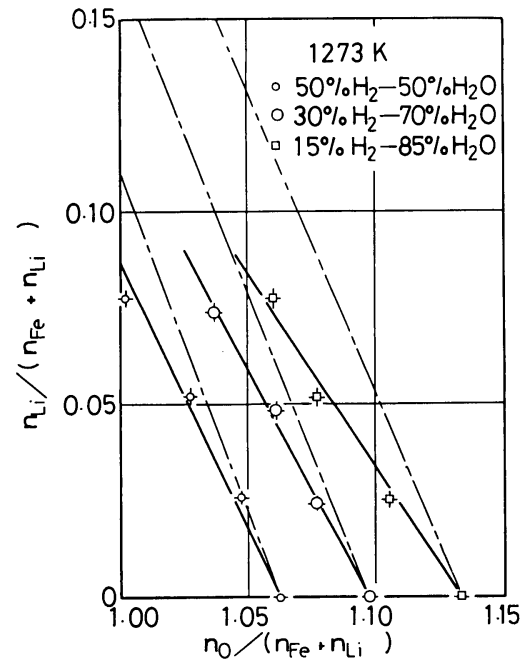

Fig.4 Variation of $Y$ (mole fraction of $\mathrm{Li}$ to total moles of metals) with $X$ (mole fraction of oxygen to total moles of metals) at the three oxygen pressures. - : relation betwee $Y$ and $X$ calculated on the assumption of an ideal solid solution in the binary system of $\mathrm{FeO}-\mathrm{Li}_{2} \mathrm{O}$.

\section{V. 考察}

\section{Fe-Na-O 系についての従来の結果との対応}

Balkhi ら (2)(11) Fig.2 と示した $\mathrm{Fe}$ と平衡する $\mathrm{Na}$ ウ スタイト，マグネタイトと平衡する $\mathrm{Na}$ ウスタイトの組成 
をカプセル中で平衡させたのち急冷した試料の化学分析に よって決定した．本研究の $50 \% \mathrm{H}_{2}-50 \% \mathrm{H}_{2} \mathrm{O}$ の等酸素圧線 —Elliott, Gleiser の熱力学データ ${ }^{(16)}$ から計算した酸素 分圧 $P_{\mathrm{O}_{2}}=2.87 \times 10^{-10} \mathrm{~Pa}$ 一《彼らの求めた $\mathrm{Fe}$ と平衡 した Na ウスタイトの組成を越えている.

理論的に $\mathrm{Fe}$ と $\mathrm{FeO}$ 平衡の酸素分圧より大きい $50 \% \mathrm{H}_{2}$ $50 \% \mathrm{H}_{2} \mathrm{O}$ の等酸素圧線は $\mathrm{Fe}$ と $\mathrm{Na}$ ウスタイト平衡線を越 壳ない. Balkhi ら ${ }^{(2)}$ は分析精度を良くするためカプセル 中で $\mathrm{Fe}$ と $\mathrm{Na}$ ウスタイトを分離して気相を通じて平衡さ せる方法を採って批り，彼ら自身も記しているようにこの 点が平衡値を得るのに不十分である。これが不一致の一因 と考光られる。

また $15 \% \mathrm{H}_{2}-85 \% \mathrm{H}_{2} \mathrm{O}$ の等酸素圧線— $P_{\mathrm{O}_{2}}=9.22 \times 10^{-9}$ $\mathrm{Pa}$ —は Balkhi ら ${ }^{(2)}$ の報告しているマグネタイトと平衡 したウスタイトの組成を越兄ている。彼らは急冷した 試料の磁気分析から試料中のマグネタイト量を算出し, マグネタイト中の $\mathrm{Na}$ 濃度とウスタイト中の $\mathrm{Na}$ 濃度の関 係を仮定して，上記組成を決定した。しかし，ウスタイト を急冷する際に一一特にマグネタイトとの平衡組成に近い ウスタイトほど顕著に一ーマグネタイトが析出することは よく知られている事実(14)であり，Balkhi ら ${ }^{(2)}$ はウスタイ 卜領域を狭く見積り過ぎている。これが本研究との不一致 の一因と考光られる。

また, 最近 $\mathrm{Dai} ら^{(1)}$ が $\mathrm{Fe}$ と $\mathrm{Na}$ ウスタイト平衡の酸素 分圧を安定化ジルコニアを使ったセルによって測定してい るが，Na ウスタイトの組成が明確に示されていないし理 論上明確に示せないはずなので本研究との比較に使えな w.

なお，Li ウスタイトについてはこれまで研究されてい ない。

\section{2. 熱力学的検討}

まず始めに $\mathrm{FeO}$ 固溶体のカチオン構成要素間に会合錯 体は生成されないとの仮定のもとに反応式(11)，(12)によ って解析を行った。

$3 \mathrm{Fe}_{\mathrm{Fe}}^{\times}+1 / 2 \mathrm{O}_{2}(\mathrm{~g})=\mathrm{V}_{\mathrm{Fe}}^{\prime \prime}+2 \mathrm{Fe} \dot{\mathrm{Fe}}_{\mathrm{e}}+\mathrm{FeO}$

$2 \mathrm{Fe}_{\mathrm{Fe}}+2 \mathrm{M}_{\mathrm{Fe}}^{\prime}+1 / 2 \mathrm{O}_{2}(\mathrm{~g})=2 \mathrm{Fe}_{\mathrm{Fe}}+2 \mathrm{~V}_{\mathrm{Fe}}^{\prime \prime}+\mathrm{M}_{2} \mathrm{O}$

しかし，実験結果をこれらの式によって整理したところ， 反応の見掛けの平衡定数 $K_{11}^{\prime}, K_{12}^{\prime}$ の対数は $\left(\mathrm{V}_{\mathrm{Fe}}^{\prime \prime}\right),\left(\mathrm{M}_{\mathrm{Fe}}^{\prime}\right)$ の複雑な関数となった。そこで, 構成要素間に会合錯体が 生成されるとして以下に考察を進めた。

前報 ${ }^{(13)}$ のアルカリ土類金属酸化物を固溶した $\mathrm{FeO}$ につ いては，カチオン構成要素は $\mathrm{Fe}$ Fe $, \mathrm{Fe}_{\mathrm{Fe}}^{\dot{x}}, \mathrm{Me}_{\mathrm{Fe}}^{\times}, \mathrm{V}_{\mathrm{Fe}}^{\prime \prime} か ゙$ 考 えられる、 $\mathrm{MeO}$ の種類によって $\left(\mathrm{V}_{\mathrm{Fe}}^{\prime \prime}\right)$ が大きく異なる実験 結果を説明するため, $\mathrm{Me}$ Fe と他の構成要素の間の相互作 用としては静電気的相互作用は考兄られず，イオン半径の 違いから生ずる $\mathrm{Me}_{\mathrm{Fe}}^{\times}$のまわりの弾性歪を緩和する $\mathrm{Me}_{\mathrm{Fe}}^{\mathrm{x}}$ と V Fe $^{\prime \prime}$ の相互作用を考光た。

アルカリ金属酸化物を固溶した $\mathrm{FeO}$ については，カチ
オン構成要素は $\mathrm{Fe}_{\mathrm{Fe}}^{\times}, \mathrm{Fe}_{\mathrm{Fe}}, \mathrm{M}_{\mathrm{Fe}}^{\prime}, \mathrm{V}_{\mathrm{Fe}}^{\prime}$ が考兄られ，イオ ン半径の違いによる $\mathrm{M}_{\mathrm{Fe}}^{\prime}$ のまわりの弾性歪を緩和する $\mathrm{M}_{\mathrm{Fe}}^{\prime}$ と $\mathrm{V}_{\mathrm{Fe}}^{\prime \prime}$ の相互作用の外倩電気的相互作用として $\mathrm{M}_{\mathrm{Fe}}^{\prime}$ と $\mathrm{V}_{\mathrm{Fe}}^{\prime \prime}$ の間の斥力的相互作用, $\mathrm{V}_{\mathrm{Fe}}^{\prime \prime}$ と $\mathrm{Fe}_{\mathrm{Fe}}, \mathrm{M}_{\mathrm{Fe}}^{\prime}$ と $\mathrm{Fe}_{\mathrm{Fe}}$ の間の引力的相互作用が考劣られる. $\mathrm{FeO}$ 固溶体 は $\mathrm{NaCl}$ 構造であるからカチオン，アニオンとも配位数 6 である、このときの $\mathrm{Fe}^{2+}, \mathrm{Na}^{+}, \mathrm{Li}^{+}$のイオン半径 ${ }^{(17)}$ はとれ ぞれ $0.077,0.102,0.074 \mathrm{~nm}$ である. イオン半径につい てみると $\mathrm{Na}^{+}>\mathrm{Fe}^{2+}>\mathrm{Li}^{+}$であるにもかかわらず，Fig.3， 4 と示したように $\mathrm{Na}_{2} \mathrm{O}$ と $\mathrm{Li}_{2} \mathrm{O}$ がほとんど同じ挙動を示 していることから，本研究では静電気的相互作用の方が大 きいと考皃た。

$\mathrm{FeO}-\mathrm{Fe}_{2} \mathrm{O}_{3}-\mathrm{MgO}$ 系固溶体之酸素の平衡についての Engell ら ${ }^{(18)}$ の研究では $\left[\mathrm{Fe}_{\mathrm{Fe}} \mathrm{V}_{\mathrm{Fe}}^{\prime} \mathrm{Fe}_{\dot{\mathrm{Fe}}}\right]$ の電気的に中性な 会合錯体の生成が考光られている。また， $\left[\mathrm{Fe}_{\mathrm{Mg}} \mathrm{V}_{\mathrm{Mg}}^{\prime \prime} \mathrm{Fe} \dot{\mathrm{M}}_{\mathrm{g}}\right]$ のかたちの会合錯体はメスバウアスペクトル測定 ${ }^{(19)}$ とよ って存在が確められている。 これに対応して考光れば, 本

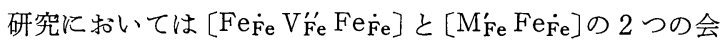
合錯体の生成を考光るのが妥当であるう，2 つの会合錯体 生成反応は式(13)，(14)で表わされる。

$$
3 \mathrm{Fe}_{\mathrm{Fe}}^{\times}+1 / 2 \mathrm{O}_{2}(\mathrm{~g})=\left[\mathrm{Fe}_{\mathrm{Fe}} \mathrm{V}_{\mathrm{Fe}}^{\prime \prime} \mathrm{Fe} \dot{\mathrm{Fe}}_{\mathrm{e}}\right]+\mathrm{FeO}
$$

$2 \mathrm{Fe}_{\mathrm{Fe}}^{\times}+2\left[\mathrm{M}_{\mathrm{Fe}}^{\prime} \mathrm{Fe} \dot{\mathrm{Fe}}_{\mathrm{e}}\right]+1 / 2 \mathrm{O}_{2}(\mathrm{~g})=2^{\prime \prime}\left[\mathrm{Fe}_{\mathrm{Fe}} \mathrm{V}_{\mathrm{Fe}}^{\prime \prime} \mathrm{Fe}_{\mathrm{Fe}_{\mathrm{e}}}\right]+\mathrm{M}_{2} \mathrm{O}$

ここでつぎの関係が成立する，

$$
\begin{aligned}
& \Sigma\left(\mathrm{V}_{\mathrm{Fe}}^{\prime \prime}\right)=\left(\left[\mathrm{Fe}_{\mathrm{Fe}} \mathrm{V}_{\mathrm{Fe}}^{\prime \prime} \mathrm{Fe}_{\dot{\mathrm{Fe}}}\right]\right) \\
& \Sigma(\mathrm{Fe} \dot{\mathrm{Fe}})=2\left(\left[\mathrm{Fe}_{\mathrm{Fe}} \mathrm{V}_{\mathrm{Fe}}^{\prime \prime} \mathrm{Fe}_{\mathrm{Fe}}\right]\right)+\left(\left[\mathrm{M}_{\mathrm{Fe}}^{\prime} \mathrm{Fe}_{\mathrm{Fe}}\right]\right) \\
& \Sigma\left(\mathrm{M}_{\mathrm{Fe}}^{\prime}\right)=\left(\left[\mathrm{M}_{\mathrm{Fe}}^{\prime} \mathrm{Fe}_{\mathrm{Fe}}\right]\right) \\
& \text { ただし }, \sum \text { は合計を意味する. }
\end{aligned}
$$

式(15)〜(17) に执いて $\mathrm{FeO}$ と $\mathrm{M}_{2} \mathrm{O}$ が擬 2 元系であり， $\mathrm{M}_{2} \mathrm{O}$ の固溶量が小さいので $\mathrm{FeO}$ については Raoult 則が $\mathrm{M}_{2} \mathrm{O}$ については Henry 則が成立しているとみなすことが できる. $\mathrm{FeO}$ と $\mathrm{M}_{2} \mathrm{O}$ の活量は擬 2 元系としてのそれぞれ の $\mathrm{mol}$ 分率 $N_{\mathrm{FeO}}, N_{\mathrm{M}_{2} \mathrm{O}}$ に比例する。平衡酸素分圧 $P_{\mathrm{O}_{2}}$ は反応 $\mathrm{H}_{2}(\mathrm{~g})+1 / 2 \mathrm{O}_{2}(\mathrm{~g})=\mathrm{H}_{2} \mathrm{O}(\mathrm{g})$ の標準生成自由エネル ギーの文献値 ${ }^{(16)}$ を使って計算した。実験結果から計算し た濃度を代入して求めた見掛けの平衡定数 $K_{13}^{\prime}, K_{14}^{\prime}$ を Fig.5, 6 亿示す. $\log K_{13}^{\prime}$ は $1173,1273 \mathrm{~K}$ とも $\left(\mathrm{M}_{\mathrm{Fe}}^{\prime}\right)$ と直 線的関係洫る。一方, $\log K_{14}^{\prime}$ 子 $1173,1273 \mathrm{~K}$ の 2 つの

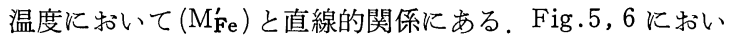
て各 $P_{\mathrm{H}_{2} \mathrm{O}} / P_{\mathrm{H}_{2}}$ 比ごとに最小自乗法によって $\log K_{13}^{\prime}$, $\log K_{14}^{\prime}$ と $\left(\mathrm{M}_{\mathrm{Fe}}^{\prime}\right)$ の間の直線関係の方程式を求め, その方 程式にもとづいて $Y$ と $X$ の関係を計算した結果は Fig.3， 4 の実験結果をほぼ再現することができた。ただし，K１１4 は $N_{\mathrm{M}_{2} \mathrm{O}} /\left(\mathrm{M}_{\mathrm{Fe}}^{\prime}\right)^{2}$ を含むので $\left(\mathrm{M}_{\mathrm{Fe}}^{\prime}\right) \rightarrow 0$ のとき無限大に近 づく. 従って Fig.6 で直線関係が成立するのは $\left(\mathrm{M}_{\mathrm{Fe}}^{\prime}\right)$ の実 験濃度範囲飞限られる。

$\log K_{13}^{\prime}, \log K_{14}^{\prime}$ は $T$ の関数であるばかりでなく, $P_{\mathrm{O}_{2}}$, $\left(\mathrm{M}_{\mathrm{Fe}}^{\prime}\right)$ の関数ともなる。これは $K_{13}^{\prime}, K_{14}^{\prime}$ が真の平衡定数 でなく見掛けの平衡定数に過ぎないことを示している。カ 


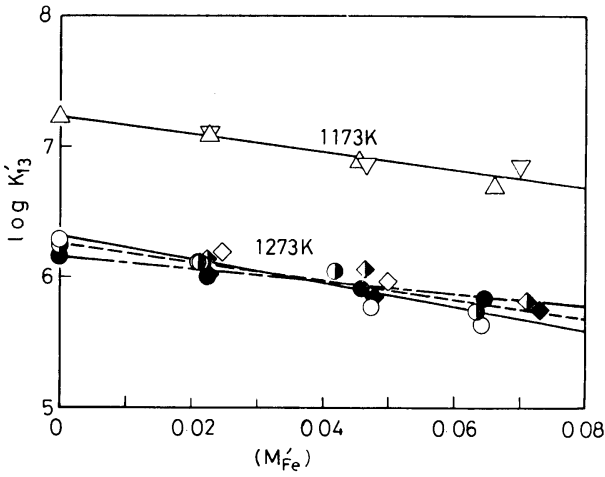

Fig. 5 Dependence of $\log K_{13}^{\prime}$ on the site fraction occupied by $\mathrm{Na}$ or $\mathrm{Li}$ in the cation sublattice.

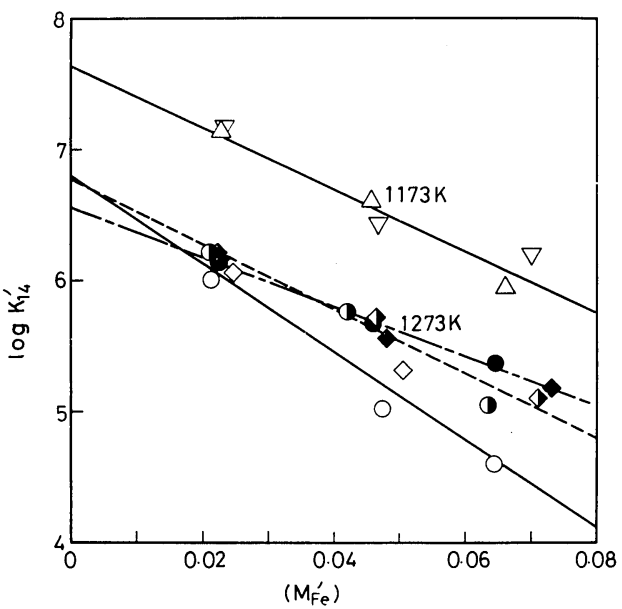

Fig.6 Dependence of $\log K_{14}^{\prime}$ on the site fraction occupied by $\mathrm{Na}$ or $\mathrm{Li}$ in the cation sublattice.

チオンサイトを占めるものとして考光た $\left[\mathrm{Fe}_{\mathrm{Fe}} \mathrm{V}_{\mathrm{Fe}}^{\prime \prime} \mathrm{Fe} \dot{\mathrm{Fe}}\right]$ と $\left[\mathrm{M}_{\mathrm{Fe}}^{\prime} \mathrm{Fe} \dot{\mathrm{Fe}}\right]$ の 2 つ会 合錯体と $\mathrm{Fe}_{\mathrm{Fe}}^{\times}$が相互作用を持って いるとした溶液モデルが $\mathrm{M}_{2} \mathrm{O}$ を含む $\mathrm{FeO}$ 固溶体に適用で きたということである。

純粋なウスタイトについてさ学も統計力学的取り扱 い(20)(21) は十分には成功していないし, さらにクラスター

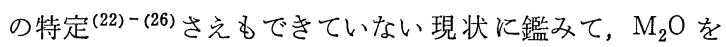
固溶したウスタイトについての本研究においては溶液モデ ル的取り扱いを行った。

な技, Engel1 ら(18)のマグネシオウスタイト固溶体につ いての研究によれば $Y^{\prime}=n_{\mathrm{Mg}} /\left(n_{\mathrm{Fe}}+n_{\mathrm{Mg}}\right)>0.8$ の組成範 囲に打いては, 本研究の反応式 (13) に対応する反応式

$2 \mathrm{Fe}_{\mathrm{Mg}}^{\times}+\mathrm{Mg}_{\mathrm{Mg}}^{\times}+1 / 2 \mathrm{O}_{2}(\mathrm{~g})=\left[\mathrm{Fe}_{\dot{\mathrm{Fe}}} \mathrm{V}_{\mathrm{Fe}}^{\prime \prime} \mathrm{Fe}_{\dot{\mathrm{Fe}}}\right]=\mathrm{MgO}$ (18) が適用でき $K_{18}^{\prime}$ が組成に依存しない。しかし， $Y^{\prime}<0.6$ あ るいは $P_{\mathrm{O}_{2}}$ が大きいとき会 合錯体 $\left[\mathrm{Fe}_{\mathrm{Fe}} \mathrm{V}_{\mathrm{Fe}}^{\prime \prime} \mathrm{Fe}_{\mathrm{Fe}}\right]$ 間に相 互作用を考慮した Brynestad と Flood ${ }^{(20)}$ の統計力学的モ デルの方がより実験結果への適合性がよい。しかし，その 見掛けの平衡定数は組成に依存する。これからみても本研 究のように $\mathrm{Fe}$ 濃度の高いウスタイト固溶体範囲では単純 なモデルが適用できないことが分かる。

\section{3. 実験䛈差についての検討}

平衡試料調製時の $P_{\mathrm{H}_{2} \mathrm{O}} / P_{\mathrm{H}_{2}}$ 比は水蒸気飽和前の $P_{\mathrm{Ar}} /$ $P_{\mathrm{H}_{2}}$ 比の $\pm 1.2 \%$ 変動によって $\pm 0.3 \%$, 水温の $\pm 0.2 \mathrm{~K}$ の変動によって $1 \%$ の誤差が見込まれる。水温から計算 した $P_{\mathrm{H}_{2} \mathrm{O}}$ はU字管で吸湿して求めた $P_{\mathrm{H}_{2} \mathrm{O}}$ より約 $1.5 \%$ 大きかったので補正した，以上の䛊差の合計は $\left(\mathrm{V}_{\mathrm{Fe}}^{\prime \prime}\right)$ 值に 対して \pm 0.003 程度である.

平衡試料作製時に試料から $\mathrm{M}_{2} \mathrm{O}$ がわずかに蒸発するの で,その蒸発によって生ずる可能性のある試料内 $\mathrm{M}_{2} \mathrm{O}$ 濃度 不均一については試料タブレットを同一組成の粉体中に埋 め込むことによって防止したが最大 $\left(\mathrm{M}_{\mathrm{Fe}}^{\prime}\right)$ 值にして士5\% 程度の䛊差を伴う可能性がある。

平衡試料を還元法で分析するときの $\mathrm{Fe}$ の蒸発は試料 1 個あたり $0.5 \mathrm{mg}$ 程度と推定され，これによって $\left(\mathrm{V}_{\mathrm{Fe}}^{\prime \prime}\right)$ 値 を 0.0016 見掛上大きくする。

また炎光分析による $\mathrm{Na}, \mathrm{Li}$ の分析值は 2 ケタの精度し かないが試料中に和ける濃度が低いので，これによる誤差 はきわめて小さい，さらに還元された試料中の $\mathrm{Na}$ は金属 状態で, $\mathrm{Li}$ は $\mathrm{Li}_{2} \mathrm{O}$ の状態で存在することを熱力学データ から推定したが, 一部 $\mathrm{Na}_{2} \mathrm{O}$ の残存, $\mathrm{Li}$ への還元があっ たとしてもその絶対量が少いためわずかの誤差しか入って 来ない.

以上本研究から推定される誤差を実験点を通る線分とし て Fig.3, 4 に示した.

\section{VI. 結 論}

$\mathrm{M}_{2} \mathrm{O}(\mathrm{M}=\mathrm{Na}, \mathrm{Li})$ を含んだウスタイト 固溶体を $1273 \mathrm{~K}$ に拈いて一定の $P_{\mathrm{H}_{2} \mathrm{O}} / P_{\mathrm{H}_{2}}$ 比の $\mathrm{Ar}-\mathrm{H}_{2}-\mathrm{H}_{2} \mathrm{O}$ 混合ガスと平 衡させ，還元法と炎光法で分析して組成を決定した。この 分析值から固溶体にはカチオンの侵入型の欠陷は存在しな いとの仮定のもとに, カチオン構成要素の濃度を計算し た.さらにカチオン構成要素の間で 2 つの会合錯体を含む つぎの反応式

$3 \mathrm{Fe}_{\mathrm{Fe}}^{\stackrel{x}{F}}+1 / 2 \mathrm{O}_{2}(\mathrm{~g})=\left[\mathrm{Fe}_{\mathrm{Fe}} \mathrm{V}_{\mathrm{Fe}}^{\prime \prime} \mathrm{Fe}_{\mathrm{Fe}}\right]+\mathrm{FeO}$

$2 \mathrm{Fe}_{\mathrm{Fe}}^{\times}+2\left[\mathrm{M}_{\mathrm{Fe}}^{\prime} \mathrm{Fe}_{\dot{\mathrm{Fe}}}\right]+1 / 2 \mathrm{O}_{2}(\mathrm{~g})=2\left[\mathrm{Fe}_{\dot{\mathrm{Fe}}} \mathrm{V}_{\mathrm{Fe}}^{\prime \prime} \mathrm{Fe}_{\dot{\mathrm{Fe}}}\right]$

$$
+\mathrm{M}_{2} \mathrm{O}
$$

を考え，さらに，会合錯体間に相互作用を仮定することに よって実験結果をほぼ説明することができた。

終りに, 一部の計算を行った本学助手の山口 周工学博 士に感謝する.

\section{文献}

(1) W.Dai, S.Seetharaman and L.-I.Staffansson : Met. Trans., 15B (1984), 319.

(2) A.M.E1.Balkhi, M.Zanne, C.Gleitzer and J. Aubry : Mem. Sci.Rev. Met., 73 (1976), 761.

(3) R.Knick and E.J.Kohlmeyer : Anorg. Allgem. Chem., 244 (1940), 67.

(4) E.G.King : J.Am.Chem.Soc., 73 (1951), 3189. 
(5) O.Kubaschewski : High Temp.-High Pressure, $4(1972), 1$.

(6) J.Thery: Ann. Chim., 7 (1962), 207.

(7) M.G.Barker and D.J.Wood : J.Less-Common Met., 35 (1974), 315.

(8) P.Gross and P.L.Wilson : J.Chem. Soc. (A), $11(1970), 1913$.

(9) B.J.Shaiu, P.C.S.Wu and P.Chiotti:J.Nuclear Mat., 67 (1977) , 13.

(10) P.C.S.Wu, P.Chiotti and J. T. Mason : Proc. International Conf. on Liquid Metal Technology in Energy Production, M.H.Cooper Ed., NTIS, Springfield, VA, 1976, publ. 1977, vol.2, 638.

(11) J.M.Claude, A.M.El Balkhi, F.Jeannot, C. Gleitzer and J.Aubry : Mem. Sci. Rev. Met., 72 (1975), 599.

(12) W.Dai, S.Seetharaman and L.-I.Staffansson : Scand. J.Metal., 13 (1984), 32.

（13）井口義章, 窪小谷良一, 平尾次郎：日本金属学会 誌, $49(1985), 279$.

(14) R.L.Levin and J.B.Wagner, Jr. : Trans. Met. Soc. AIME, 236(1966), 516.

(15) F.A.Kröger:The Chemistry of Imperfect Crystals, vol.2, 2.ed., North-Holland Publ. Comp., Amsterdam, (1974), 14.
(16) J.F.Elliott and M.Gleiser : Thermochemistry for Steelmaking, Addition-Wesley, Massachusetts, (1960), 176.

(17) W.D.Kingery, H.K.Bowen and D.R.Uhlmann: Introduction to Ceramics, 2nd ed., John Wiley \& Sons, New York, (1976), 58.

(18) P.-M.Valet, W.Pluschkell and H.-J.Engell : Arch. Eisenhüttenw., 46(1975), 383.

(19) V.G.Bhide and B.R.Tambe:J.Mat.Sci., 4 (1969), 955.

(20) J.Brynestad and H.Flood : Z.Elektrochem., 62 (1958), 953.

(21) 竹内 栄, 井垣謙三: 日本金属学会誌, B14 (1950), 28.

(22) A.K.Cheetham, B.E.F.Fender and R.I.Taylor: J.Phys.C : Solid State, 4(1971), 2160.

(23) C.R.A.Catlow and B.E.F.Fender : J.Phys.C : Solid State, 8(1975), 3267.

(24) J.D.Hodge:J.Amer. Ceram. Soc., 64 (1981), 431

(25) F.Koch and J.B.Cohen:Acta Cryst., 1325 (1969) 275 .

(26) C.R.A.Catlow and A.M.Stoneham : J.Amer. Ceram.Soc., 64 (1981) , 234.

(27) R.Tetot and P.Gerdanian:J.Phys.Chem.Solids, $46(1985), 869$. 